\title{
Recent Discovery of Amaranthus palmeri S. Watson in Italy: Characterization of ALS-Resistant Populations and Sensitivity to Alternative Herbicides
}

\author{
Andrea Milani ${ }^{1} \oplus$, Silvia Panozzo ${ }^{1}$, Silvia Farinati ${ }^{1}$, Duilio Iamonico ${ }^{2}$, Maurizio Sattin ${ }^{1}\left(\right.$, Donato Loddo ${ }^{1}(\mathbb{D}$ and \\ Laura Scarabel ${ }^{1, *}$ \\ 1 Institute for Sustainable Plant Protection (IPSP-CNR), 35020 Legnaro, Italy; andrea.milani@ipsp.cnr.it (A.M.); \\ silvia.panozzo@cnr.it (S.P.); farinati.silvia@gmail.com (S.F.); maurizio.sattin@cnr.it (M.S.); \\ donato.loddo@cnr.it (D.L.) \\ 2 Department of Planning, Design, and Technology of Architecture (PDTA), University of Rome Sapienza, \\ 00196 Rome, Italy; d.iamonico@yahoo.it \\ * Correspondence: laura.scarabel@cnr.it; Tel.: +39-0498-272-822
}

check for updates

Citation: Milani, A.; Panozzo, S.; Farinati, S.; Iamonico, D.; Sattin, M.; Loddo, D.; Scarabel, L. Recent Discovery of Amaranthus palmeri S. Watson in Italy: Characterization of ALS-Resistant Populations and Sensitivity to Alternative Herbicides. Sustainability 2021, 13, 7003. https:// doi.org/10.3390/su13137003

Academic Editor: Emanuele Radicetti

Received: 13 May 2021

Accepted: 18 June 2021

Published: 22 June 2021

Publisher's Note: MDPI stays neutral with regard to jurisdictional claims in published maps and institutional affiliations.

Copyright: (C) 2021 by the authors Licensee MDPI, Basel, Switzerland. This article is an open access article distributed under the terms and conditions of the Creative Commons Attribution (CC BY) license (https:// creativecommons.org/licenses/by/ $4.0 /)$.

\begin{abstract}
Amaranthus palmeri S. Watson (Amaranthaceae Juss.) is a dioecious noxious weed, native to the Americas, which infests summer crops. It causes high crop losses, and rapidly evolves resistance to herbicides. In Europe, A. palmeri was recorded mostly as a casual alien, but in 2018 it was reported infesting a soybean field in Italy, and the next year two more populations were found in the same area. Experiments were conducted on these three populations to evaluate the resistance to ALSinhibiting herbicides, to determine the main resistance mechanisms involved and assess the efficacy of alternative herbicides with different sites of action than ALS. The three populations were confirmed cross-resistant to ALS-inhibiting herbicides (thifensulfuron-methyl and imazamox). Gene sequencing identified a Trp to Leu substitution at position 574 of $A L S$ gene in resistant plants, proving that the main resistance mechanism for the three populations is target-site related. The presence of other resistance mechanisms cannot be excluded. Metobromuron, metribuzin and glyphosate are still effective on these populations.
\end{abstract}

Keywords: herbicide resistance; palmer amaranth; alternative herbicides; soybean

\section{Introduction}

Amaranthus palmeri S. Watson (Amaranthaceae Juss.), commonly known as palmer amaranth or careless weed, is a dioecious noxious weed naturally distributed from Northern Mexico to southwest North America [1]. Outside its native range, A. palmeri occurs as alien species in all continents. In Europe it is considered as a casual alien in most countries and naturalized in a few (Belarus, Greece, Italy, Lithuania, Spain and Sweden), where it grows on human-made habitats, especially along roads [2]. In Italy, A. palmeri was found for the first time in 2014 in the Emilia Romagna region (NE-Italy) and recorded as casual along a major route [3]. The species was also recorded in Piedmont region (NW-Italy) on a riverbank and under a railway bridge [4]. In 2018, A. palmeri was found in a soybean field in the Veneto region (NE-Italy) [5]. In 2019, two more populations were found, 10 and $22 \mathrm{~km}$ far from that site, again in soybean. In 2020, the species was scouted for the first time in Lombardy, in a harvested corn field [6].

A wide range of pre-emergence and post-emergence herbicides are available to control A. palmeri in soybean. However, worldwide, $A$. palmeri has evolved resistance to eight sites of action (SoA) [7] and a population from Kansas has evolved multiple resistance to up to six SoA [8]. All records of herbicide resistant A. palmeri were found in the United States until 2008, when it was first reported in Israel [9], then in Brazil [10], Argentina [11] and, more recently, in Spain, where the introduction of already resistant biotypes was suspected [12]. 
The most common mechanism endowing ALS inhibitors resistance in A. palmeri is target-site mediated and involves several point mutations at the ALS gene [13], but a few cases of non-target-site mechanism have recently been reported $[8,14]$. Due to both economic and environmental factors, post-emergence application of ALS-inhibiting herbicides is the most common weed control strategy in soybean in Italy, and it is likely one of the driving factors of the recent spreading of ALS-resistant amaranths [15]. Several herbicides with alternative sites of action, such as inhibitors of photosystem (PS) I and II, 5-enolpyruvylshikimate-3-phosphate (EPSP) synthase and carotenoid biosynthesis can provide effective control of ALS-resistant populations of A. palmeri $[16,17]$. However, given the ability of this species to evolve resistance against herbicides with different sites of action [18], the efficacy of potential alternative herbicides should be assessed at local level before recommending their use.

The aims of this work were (i) to verify the resistance status to ALS-inhibiting herbicides of three Italian A. palmeri populations; (ii) to determine the main resistance mechanisms involved; and (iii) to evaluate the efficacy of alternative herbicides with different sites of action than ALS.

\section{Materials and Methods}

\subsection{Plant Material}

Three A. palmeri populations were collected in north-eastern Italy in soybean fields where poor herbicide control was suspected. For each population, seeds were collected from at least 30 female plants, randomly distributed across the field. Population 18-100 was collected in 2018 and a voucher herbarium specimen was deposited at La Sapienza University of Rome (Herbarium FIaminio, HFLA) [5]. Populations 19-174 and 19-177 were collected in 2019. In addition, an American susceptible A. palmeri check (kindly provided by Prof. T. A. Gaines [19]) was used as susceptible reference population (20-179).

\subsection{Herbicide Bioassays}

Bioassays with post-emergence and pre-emergence herbicides were conducted twice, in a greenhouse located in north-eastern Italy $\left(45^{\circ} 21^{\prime} \mathrm{N}, 11^{\circ} 58^{\prime} \mathrm{E}\right)$. Greenhouse temperatures varied between 15 and $20^{\circ} \mathrm{C}$ and from 25 to $34{ }^{\circ} \mathrm{C}$, during the night and day, respectively.

For experiments with herbicides applied in post-emergence, seed germination, seedlings growth and herbicide treatments were done as previously described [20]. In brief, seeds were sown in transparent plastic boxes (diameter $12 \mathrm{~cm}$, height $5 \mathrm{~cm}$ ) containing $50 \mathrm{~mL}$ of $0.6 \%$ agar; after 1 week at $4{ }^{\circ} \mathrm{C}$ (dark), the boxes were transferred into a germination cabinet at alternating light and temperature to stimulate germination: $12 \mathrm{~h} \mathrm{light,} 28^{\circ} \mathrm{C}$ and $12 \mathrm{~h}$ dark, $18^{\circ} \mathrm{C}$. After 5 days, seedlings were transplanted into plastic trays $\left(325 \times 265 \times 95 \mathrm{~mm}^{3}, 20\right.$ plants each) with a standard potting mix ( $60 \%$ clay loam soil, $15 \%$ sand, $15 \%$ perlite and $10 \%$ peat) and watered as required. Just prior to the treatment, plants in each tray were counted. Threeto four-leaf stage plants, corresponding to growth stage 13-14 of the $\mathrm{BBCH}$ scale [21], were treated with ALS inhibitors at the recommended field rates $(1 \times)$ and three times that $(3 \times)$ : thifensulfuron-methyl 6 and $18 \mathrm{~g}$ a.i. ha ${ }^{-1}$ (Harmony $50 \mathrm{SX}$, DuPont ${ }^{\mathrm{TM}}, 500 \mathrm{~g}$ a.i. $1 \mathrm{~kg}^{-1}$ ), imazamox 40 and $120 \mathrm{~g}$ a.i. ha $^{-1}$ (Tuareg $^{\circledR}$, DuPont ${ }^{\mathrm{TM}}, 40 \mathrm{~g}$ a.i. $\mathrm{L}^{-1}$ ). Glyphosate was applied at the field rate: $480 \mathrm{~g}$ a.i. $\mathrm{ha}^{-1}$ (Roundup Platinum ${ }^{\circledR}$, Monsanto, $480 \mathrm{~g}$ a.i. $\mathrm{L}^{-1}$ ). Agrochemicals were applied using a precision bench sprayer delivering $300 \mathrm{~L} \mathrm{ha}^{-1}$ at a pressure of $215 \mathrm{kPa}$ and speed of about $0.75 \mathrm{~m} \mathrm{~s}^{-1}$, with a boom equipped with three flat-fan (extended range) hydraulic nozzles (Teejet, 11002). The experimental layout was a complete randomized design with two replicates (trays).

Four weeks after herbicide application, the number of surviving plants and visual estimation of their biomass (VEB) were assessed. The VEB scores, ranging from 100 (for plants not affected by the herbicide, equal to the untreated control) to 0 (when the plants were clearly dead), were given to each treated tray. Standard error (SE) was calculated for each data mean. 
For experiments with herbicides applied in pre-emergence, the same kind of trays used for post-emergence experiments were filled with a potting mix with no peat. A layer of sterilized clay loam soil was added on top $\left(3\right.$ days at $105^{\circ} \mathrm{C}, 2-3 \mathrm{~cm}$, organic matter $1.1 \mathrm{mg} \mathrm{kg}^{-1}$ of dry matter). Seeds were soaked in a transparent plastic box with a wet paper filter for 3 days at $4{ }^{\circ} \mathrm{C}$ (dark), then transferred into a germination cabinet for $24 \mathrm{~h}, 12 \mathrm{~h}$ light at $28^{\circ} \mathrm{C}$ and $12 \mathrm{~h}$ dark at $18{ }^{\circ} \mathrm{C}$ to stimulate germination. Seeds were then gently wiped with paper and sown in trays ( 50 seeds per tray). Seeds were then covered with a layer of 1-2 mm of the sterilized soil. An aluminum foil pan was placed at the base of each tray and water was distributed both by sprinkler irrigation and by filling the pan to maintain soil moisture. The experimental layout was a complete randomized design with 3 replicates (trays) per treated thesis and 4 replicates per non-treated thesis. Twenty-four hours after sowing, pre-emergence herbicides were applied at the field rates: metribuzin $245 \mathrm{~g}$ a.i. ha ${ }^{-1}$ (Feinzin ${ }^{\circledR} 70$ DF, Adama, 70 g a.i. $100 \mathrm{~g}^{-1}$ ), metobromuron 1500 g a.i. ha ${ }^{-1}$ (Proman Flow ${ }^{\circledR}$, Belchim Crop Protection, $500 \mathrm{~g}$ a.i. $1000 \mathrm{~g}^{-1}$ ), clomazone $144 \mathrm{~g}$ a.i. ha ${ }^{-1}\left(\right.$ Sirtaki $^{\circledR}$, Sipcam, $360 \mathrm{~g}$ a.i. $1000 \mathrm{~mL}^{-1}$ ). Pre-emergence herbicide application was done with the same precision bench sprayer and same settings as for the post-emergence application. Two weeks after herbicide application, the number of seedlings and shoot fresh weight were recorded. The percentage of plant survival was calculated as the ratio between the emerged seedlings of treated trays with respect to those of non-treated trays. The relative fresh weight was calculated as the ratio between the fresh weight of treated trays with respect to that of non-treated trays. Standard error (SE) was calculated for each data mean.

\subsection{DNA Extraction and Detection of Mutated ALS Alleles}

DNA was extracted from 15 plants that survived the field dose of thifensulfuron-methyl treatment, following a CTAB protocol [22]. The domain B of $A L S$ was amplified using the PCR protocol previously described for Amaranthus retroflexus [19], with primers AMA-2F (5'-TCCCGGTTAAAATCATGCTC-3') and AMA-2R (5'-CTTCTTCCATCACCCTCTGT-3'). PCR were performed using GoTaq ${ }^{\circledR}$ G2 Hot Start Polymerase (Promega) in a $25 \mu \mathrm{L}$ mixture including $5 \mu \mathrm{L}$ of $5 \times$ Green GoTaq Flexi Buffer, dNTPs mix ( $0.2 \mathrm{mM}$ each), $\mathrm{MgCl} 2(1.5 \mathrm{mM})$, forward and reverse primers $(0.2 \mu \mathrm{M}), 0.125 \mu \mathrm{L}$ GoTaq DNA Polymerase and $50 \mathrm{ng}$ DNA. Amplification conditions: $2 \mathrm{~min}$ at $95{ }^{\circ} \mathrm{C}$; 35 cycles of $30 \mathrm{~s}$ at $95{ }^{\circ} \mathrm{C}, 30 \mathrm{~s}$ at $58{ }^{\circ} \mathrm{C}, 40 \mathrm{~s}$ at $72{ }^{\circ} \mathrm{C} ; 5$ min at $72{ }^{\circ} \mathrm{C}$. PCR products were purified using NucleoSpin ${ }^{\circledR} \mathrm{Gel}$ and PCR Clean-up kit (Macherey-Nagel GmbH \& Co., Duren, Germany) following manufacturer's instructions. Once purified, both strands of the PCR products obtained from each plant were Sanger-sequenced by BMR Genomics (Padova, Italy) and edited with FinchTV 1.4.0. Sanger sequencing data (ab1 files) were deposited in a dedicated repository [23].

\section{Results}

\subsection{Resistance to ALS Inhibitors}

The percentage of plant survival and the visual estimation of biomass (VEB) between the two experiments were comparable (considering the SE); therefore, the data were pooled, and mean values were reported. The susceptible check (20-179) was completely controlled by both thifensulfuron-methyl (SU) and imazamox (IMI) at the field rate (Figure 1). Conversely, for populations 18-100, 19-174 and 19-177, a high percentage of plants survived both thifensulfuron-methyl and imazamox. At the recommended field rate, plant survival ranged from $77 \%$ to $86 \%$ for imazamox and from $83 \%$ to $100 \%$ for thifensulfuron-methyl. The VEB of the ALS-treated plants was also high, with values ranging from $78 \%$ to $94 \%$ and from $86 \%$ to $93 \%$ for imazamox and thifensulfuron-methyl, respectively, indicating a negligible effect of both herbicides on biomass production. Similar survival rates and VEB were recorded when the plants of the three populations were treated at three times the field rates of both ALS inhibitors (Figure 1). 


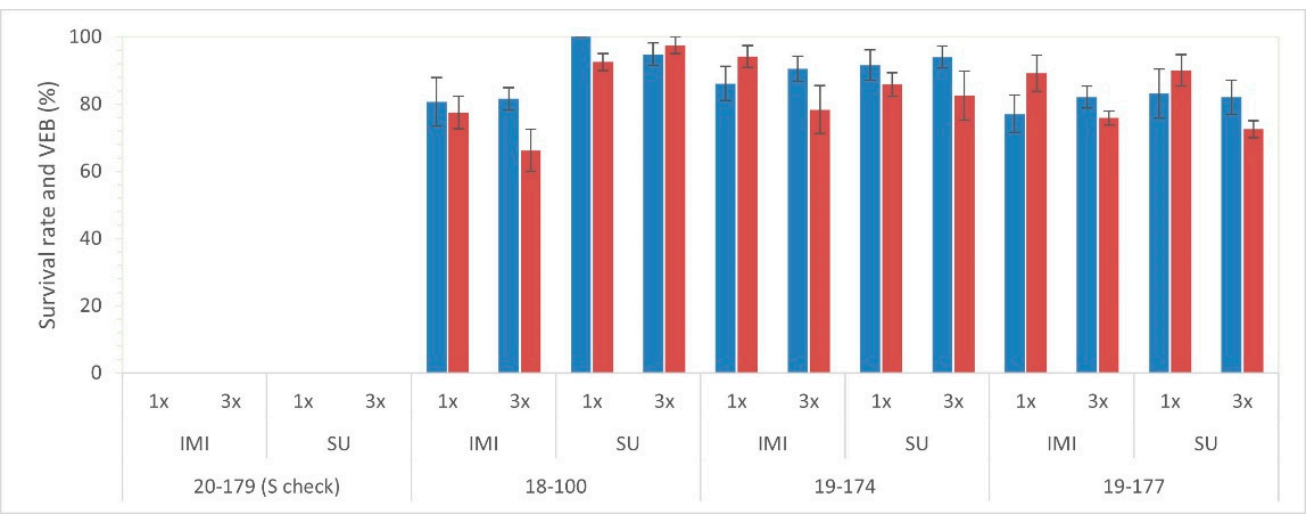

Figure 1. Response of A. palmeri populations treated with imazamox (IMI) and thifensulfuron-methyl (SU) at the field rate $(1 \times)$ and three-times that $(3 \times)$. Blue bars refer to the percentage of plant survival and red bars to the visual estimation of biomass (VEB). Vertical thin bars represent the standard error.

\subsection{Response to Non-ALS Herbicides}

All populations were completely controlled by glyphosate and no plants survived (data not shown).

In the experiments with pre-emergence herbicides, the emergence of seedlings in non-treated trays started two days after sowing. The percentages of emerged seedlings were significantly different between the two experiments (Table 1). For all populations, the efficacy of metobromuron and metribuzin was near $100 \%$ in both experiments. Instead, the percentage of plant survival and fresh weight of clomazone-treated plants varied significantly between experiments. Therefore, the data were not pooled (Figure 2, Table 2). The percentage of control for the susceptible A. palmeri population 20-179 ranged between 63 and $72 \%$, while for the ALS-resistant populations the percentage of control ranged from (approximately) 1 to $74 \%$ (Figure 2). The relative fresh weight of the plants of population 20-179 that survived to clomazone ranged between $3 \%$ and $22 \%$, while the fresh weight of the ALS-resistant populations (18-100, 19-174 and 19-177) was generally higher, with values ranging from 17 to $100 \%$ (Table 2). At the field dose, if the efficacy is lower than the $80 \%$ or the fresh weight of survivors exceed $20 \%$ of the fresh weight of non-treated controls, the chemical control is incomplete a population might be considered at risk of evolving resistance.

Table 1. Percentage of emerged seedlings of the four A. palmeri populations in non-treated conditions 14 days after sowing. Standard error in brackets.

\begin{tabular}{llccc}
\hline & & \multicolumn{3}{c}{ Population } \\
& $\mathbf{2 0 - 1 7 9}$ & $\mathbf{1 8 - 1 0 0}$ & $\mathbf{1 9 - 1 7 4}$ & $\mathbf{1 9 - 1 7 7}$ \\
\hline Experiment 1 & $69( \pm 3)$ & $49( \pm 5)$ & $32( \pm 4)$ & $35( \pm 1)$ \\
Experiment 2 & $98( \pm 7)$ & $83( \pm 4)$ & $23( \pm 1)$ & $59( \pm 4)$ \\
\hline
\end{tabular}

Table 2. Relative fresh weight of $A$. palmeri plants that survived clomazone, calculated as the ratio between the fresh weight of treated trays with respect to non-treated trays, in the first and second experiment. Standard error in brackets.

\begin{tabular}{lcccc}
\hline & & \multicolumn{3}{c}{ Population } \\
& $\mathbf{2 0 - 1 7 9}$ & $\mathbf{1 8 - 1 0 0}$ & $\mathbf{1 9 - 1 7 4}$ & $\mathbf{1 9 - 1 7 7}$ \\
\hline Experiment 1 & $3( \pm 1)$ & $51( \pm 7)$ & $17( \pm 7)$ & $100( \pm 7)$ \\
Experiment 2 & $22( \pm 14)$ & $24( \pm 7)$ & $65( \pm 15)$ & $39( \pm 13)$ \\
\hline
\end{tabular}




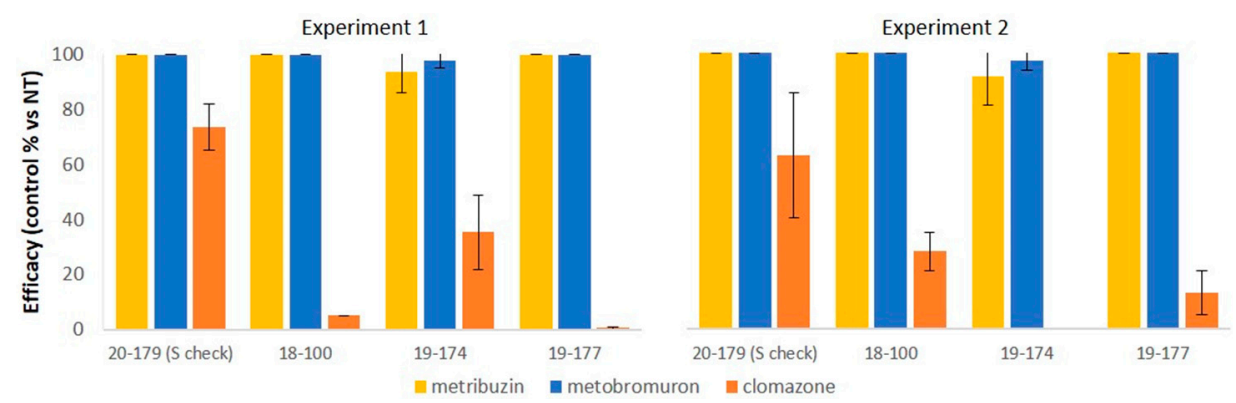

Figure 2. Herbicide efficacy (percentage of seedling reduction with respect to non-treated trays) of non-ALS herbicides on A. palmeri populations. Yellow bars for metribuzin, blue for metobromuron, orange for clomazone. Vertical thin bars represent the standard error.

\subsection{ALS Gene Mutation}

A point mutation (TGG to TTG), which caused an amino acid change from tryptophan to leucine, was found at codon 574 of $A L S$ in most plants of all resistant populations (Figure 3). Thirteen out of fifteen plants of population 18-100 were heterozygous for the mutation, while only two had no mutations at this locus. Five out of fifteen plants of population 19-174 were homozygous, seven out of fifteen plants were heterozygous, while three had no mutations at this locus. Nine out of fifteen plants of population 19-177 were heterozygous, four out of fifteen plants had no mutations at this locus, and sequencing failed for two plants. Sanger sequencing data (ab1 files) are freely accessible through a dedicated repository [23].

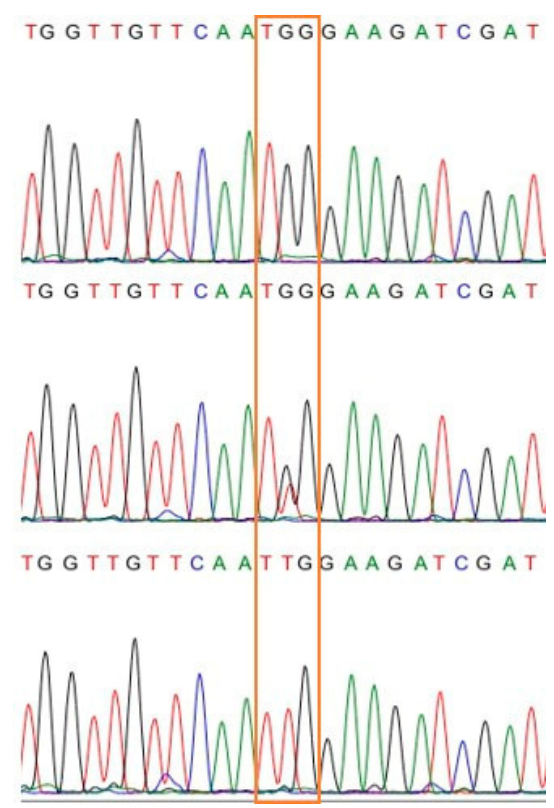

Figure 3. Chromatogram detail of ALS nucleotide sequences obtained from population 17-174, showing different point mutation at codon 574 (highlighted by the orange frame). TGG codon encodes for the amino acid tryptophan, while TTG for leucine. The double peak indicates that the plant is heterozygous.

\section{Discussion}

Three populations of A. palmeri were confirmed to be cross-resistant to thifensulfuronmethyl and imazamox. The negligible effect of these herbicides on plant biomass and the presence of the Trp574Leu substitution at $A L S$, known to confer broad spectrum resistance to ALS inhibitors in various weed species [12], proved that the main resistance mechanism is target-site related. Some plants had no mutations at position 574: the presence of other mutations or other resistance mechanisms cannot be excluded. However, target-site resis- 
tance is the main mechanism that has been reported in other A. palmeri populations. In Arkansas, a study conducted in 13 counties revealed that plants frequently had this mutation conferring a broad cross-resistance to all ALS herbicide families [24]. The Trp574Leu substitution has also been found in Brazilian A. palmeri populations [25]. Population 18-100 was the third record of $A$. palmeri in Italy and the first for the Veneto Region [5]. Finding it already resistant to ALS herbicides was surprising and alarming. A similar situation has recently been observed in Italy with the congeneric weed species Amaranthus tuberculatus (Moq.) J.D. Sauer, that has spread rather fast since appearing in agronomic habitats. Numerous ALS-resistant populations were reported in several locations [15], very likely after the introduction of ALS-resistant biotypes from outside Italy [26]. It is worth mentioning that $A$. tuberculatus had been present in Italy since the 1980s; therefore, the evolution of herbicide resistance from resident unnoticed populations was still possible (although unlikely). Instead, in the case of these three A. palmeri populations, the evolution of herbicide resistance from naturally occurring populations is very unlikely; rather, a very recent introduction from outside Italy appears to be the most plausible hypothesis. The presence of the same resistance-endowing mutation in most resistant individuals of the three populations clearly indicates that field-applied ALS inhibitors exerted a strong selective pressure. ALS-resistant populations of $A$. palmeri have also been described in Spain [12]. In that case, the populations were found along roadsides and field borders, while no persistent field infestations were reported. In those Spanish populations, the low frequency of several different mutations at $A L S$ locus, conferring resistance with different patterns may reflect a weak selective pressure due to ALS inhibitors.

The recommended field rates of glyphosate, metribuzin and metobromuron completely controlled the three ALS-resistant A. palmeri populations. Glyphosate and metribuzin are known to control A. palmeri $[27,28]$, whereas little information is available on the efficacy of metobromuron applied alone. Our results show that all three herbicides should be considered valuable options to control these A. palmeri populations. Instead, the efficacy of clomazone was weak, with variable responses between the ALS-resistant populations and an incomplete control of the susceptible check. This is in keeping with the results from other studies $[29,30]$ and with the indication that Amaranthus spp. is a "medium susceptible species" reported on the label of most herbicides containing clomazone as single active ingredient. The use of this active ingredient should be evaluated only if required to control other weed species (such as velvetleaf, Abutilon theophrasti Medik) and always in mixture with other active ingredients.

The early detection of $A$. palmeri in fields is crucial, especially when herbicide resistant. The recognition of $A$. palmeri might be easier if compared with other congeneric species, because it is morphologically well characterized [1]. Most of the Amaranthus species that are widely diffused in agricultural environments are monoecious while $A$. palmeri, together with Amaranthus tuberculatus (Moq.) J.D. Sauer, are dioecious species, thus male and female plants should be observed in the field. Flowers of female plants of A. palmeri normally have five tepals, while flowers of female plants of $A$. tuberculatus normally have 0-3 [31]. A simplified botanical key was previously developed to recognize some of the most common Amaranthus species in agronomic habitats [15].

Given the high fertility and dispersion ability of $A$. palmeri, a zero-tolerance strategy should be adopted to avoid the spread of seeds. An experiment conducted in a glyphosateresistant cotton field in the USA demonstrated that 20,000 seeds distributed in a square meter (simulating a single glyphosate resistant female palmer amaranth seed output), can infest $95-100 \%$ of the field area, causing a complete harvest loss in three years [32]. At crop harvest, infested patches should be avoided by harvest machinery [33]. Crop and herbicide rotation, mechanical weeding, hand weeding (whenever possible) and accurate cleaning of agricultural machinery are crucial to avoid further evolution of resistance. Innovative tools and tactics are progressively becoming available for farmers. For example, the adoption of harvest weed seed control (HWSC) systems could significantly contribute to the control of $A$. palmeri given its high seed retention until crop harvest [34,35]. With 1 million tons 
(Mt) produced in 2019, Italy is the third soybean producer in Europe (after Ukraine, 3.6 Mt, and the Russian Federation, $4.3 \mathrm{Mt}$ ), and the first in the European Union (before Serbia, 0.7 Mt; Romania, 0.4 Mt; and France, 0.4 Mt) [36]. Since we are, very likely, at the initial stage of the invasion and the disrupting potential of this weed is well known, every effort to eradicate it is profitable.

\section{Conclusions}

Amaranthus palmeri had not been recorded in Italy before 2015. The detection of three ALSresistant populations of $A$. palmeri in soybean is an alarming event that needs to be adequately followed up. These A. palmeri populations are cross-resistant to both thifensulfuron-methyl and imazamox. The main resistance mechanism is due to the well-known Trp to Leu substitution at position 574 of $A L S$. The presence of more than one resistance mechanism cannot be excluded. Nevertheless, herbicides with different sites of action than ALS (glyphosate, metribuzin and metobromuron) still control these populations.

Author Contributions: Conceptualization, A.M. and L.S.; Writing-Original Draft Preparation, A.M. and D.I.; Investigation, S.P. and S.F.; Writing-Review and Editing: D.L., M.S. and L.S.; Supervision, L.S. All authors have read and agreed to the published version of the manuscript.

Funding: This research received no external funding.

Institutional Review Board Statement: Not Applicable.

Informed Consent Statement: Not Applicable.

Data Availability Statement: Sanger sequencing data obtained in this study were deposited in a publicly available repository reported in references [23].

Acknowledgments: The authors are grateful to Alison Garside for revising the English text.

Conflicts of Interest: The authors declare no conflict of interest.

\section{References}

1. Mosyakin, S.L.; Robertson, K.R. Amaranthus. In Flora of North America North of Mexico Vol. 4 Magnoliophyta: Caryophillidae; Flora of North America Editorial Committee, Ed.; Oxford University Press: New York, NY, USA, 2003; pp. 410-435.

2. Iamonico, D. Amaranthus palmeri S. Watson. In: Euro+Med Plantbase-The Information Resource for Euro-Mediterranean Plant Diversity. Available online: http://ww2.bgbm.org/EuroPlusMed/PTaxonDetail.asp?NameCache=Amaranthuspalmeri\& PTRefFk=7300000 (accessed on 12 November 2020).

3. Iamonico, D.; Ardenghi, N.M.G.; Faggi, G. Euro+Med-Cheklist notulae, 4. Willdenowia 2015, 45, 119-120. [CrossRef]

4. Verloove, F.; Ardenghi, N. New distributional records of non-native vascular plants in northern Italy. Nat. Hist. Sci. 2015, 2, 5. [CrossRef]

5. Galasso, G.; Domina, G.; Adorni, M.; Angiolini, C.; Apruzzese, M.; Ardenghi, N.M.G.; Assini, S.; Aversa, M.; Bacchetta, G.; Banfi, E.; et al. Notulae to the Italian alien vascular flora: 9. Ital. Bot. 2020, 9, 71-86. [CrossRef]

6. Colombo, S. Noterella 0274: Amaranthus palmeri S.Watson. Acta Plant. Notes 2020, 7, 258.

7. Heap, I. Herbicide Resistant Weeds by Species and Site of Action. Available online: http://weedscience.org/Summary/ SpeciesbySOATable.aspx (accessed on 25 January 2021).

8. Shyam, C.; Borgato, E.A.; Peterson, D.E.; Dille, J.A.; Jugulam, M. Predominance of metabolic resistance in a six-way-resistant Palmer amaranth (Amaranthus palmeri) population. Front. Plant Sci. 2021, 11, 614618. [CrossRef]

9. Heap, I. The International Herbicide-Resistant Weed Database. Available online: http://www.weedscience.org/ (accessed on 1 October 2020).

10. Carvalho, S.J.P.; Gonçalves Netto, A.; Nicolai, M.; Cavenaghi, A.L.; López-Ovejero, R.F.; Christoffoleti, P.J. Detection of glyphosateresistant Palmer Amaranth (Amaranthus palmeri) in agricultural areas of Mato Grosso, Brazil. Planta Daninha 2015, 33, 579-586. [CrossRef]

11. Larran, A.S.; Palmieri, V.E.; Perotti, V.E.; Lieber, L.; Tuesca, D.; Permingeat, H.R. Target-site resistance to acetolactate synthase (ALS)-inhibiting herbicides in Amaranthus palmeri from Argentina. Pest Manag. Sci. 2017, 73, 2578-2584. [CrossRef]

12. Torra, J.; Royo-Esnal, A.; Romano, Y.; Osuna, M.D.; León, R.G.; Recasens, J. Amaranthus palmeri a new invasive weed in Spain with herbicide resistant biotypes. Agronomy 2020, 10, 993. [CrossRef]

13. Tranel, P.J.; Wright, T.R.; Heap, I. Mutations in Herbicide-Resistant Weeds to ALS Inhibitors. Available online: http:/ / weedscience. org/mutations/mutationdisplayall.aspx (accessed on 19 January 2021).

14. Nakka, S.; Thompson, C.R.; Peterson, D.E.; Jugulam, M. Target site-based and non-target site based resistance to ALS inhibitors in Palmer amaranth (Amaranthus palmeri). Weed Sci. 2017, 65, 681-689. [CrossRef] 
15. Milani, A.; Scarabel, L.; Sattin, M. A family affair: Resistance mechanism and alternative control of three Amaranthus species resistant to acetolactate synthase inhibitors in Italy. Pest Manag. Sci. 2020, 76, 1205-1213. [CrossRef] [PubMed]

16. Priess, G.L.; Norsworthy, J.K.; Roberts, T.L.; Gbur, E.E. Impact of postemergence herbicides on soybean injury and canopy formation. Weed Technol. 2020, 34, 727-734. [CrossRef]

17. González-Torralva, F.; Norsworthy, J.K.; Piveta, L.B.; Varanasi, V.K.; Barber, T.; Brabham, C. Susceptibility of Arkansas Palmer amaranth accessions to common herbicide sites of action. Weed Technol. 2020, 34, 770-775. [CrossRef]

18. Chaudhari, S.; Varanasi, V.K.; Nakka, S.; Bhowmik, P.C.; Thompson, C.R.; Peterson, D.E.; Currie, R.S.; Jugulam, M. Evolution of target and non-target based multiple herbicide resistance in a single Palmer amaranth (Amaranthus palmeri) population from Kansas. Weed Technol. 2020, 34, 447-453. [CrossRef]

19. Culpepper, A.S.; Grey, T.L.; Vencill, W.K.; Kichler, J.M.; Webster, T.M.; Brown, S.M.; York, A.C.; Davis, J.W.; Hanna, W.W. Glyphosate-resistant Palmer amaranth (Amaranthus palmeri) confirmed in Georgia. Weed Sci. 2006, 54, 620-626. [CrossRef]

20. Scarabel, L.; Varotto, S.; Sattin, M. A European biotype of Amaranthus retroflexus cross-resistant to ALS inhibitors and response to alternative herbicides. Weed Res. 2007, 47, 527-533. [CrossRef]

21. Hess, M.; Barralis, G.; Bleiholder, H.; Buhr, L.; Eggers, T.; Hack, H.; Stauss, R. Use of the extended BBCH scale-general for the descriptions of the growth stages of mono- and dicotyledonous weed species. Weed Res. 1997, 37, 433-441. [CrossRef]

22. Doyle, J.J.; Doyle, J.L. Isolation of plant DNA from fresh tissue. Focus (Madison) 1990, 12, 39-40.

23. Milani, A.; Panozzo, S.; Farinati, S.; Scarabel, L. Sanger sequences for "Recent discovery of Amaranthus palmeri in Italy: Characterization of ALS-resistant populations and sensitivity to alternative herbicides". Mendeley Data 2021. [CrossRef]

24. Singh, S.; Singh, V.; Salas-Perez, R.A.; Bagavathiannan, M.V.; Lawton-Rauh, A.; Roma-Burgos, N. Target-site mutation accumulation among ALS inhibitor-resistant Palmer amaranth. Pest Manag. Sci. 2019, 75, 1131-1139. [CrossRef]

25. Küpper, A.; Manmathan, H.K.; Giacomini, D.; Patterson, E.L.; McCloskey, W.B.; Gaines, T.A. Population genetic structure in glyphosate-resistant and -susceptible Palmer amaranth (Amaranthus palmeri) populations using genotyping-by-sequencing (GBS). Front. Plant Sci. 2018, 9, 29. [CrossRef] [PubMed]

26. Milani, A.; Lutz, U.; Galla, G.; Scarabel, L.; Weigel, D.; Sattin, M. Population structure and evolution of resistance to acetolactate synthase (ALS)-inhibitors in Amaranthus tuberculatus in Italy. Pest Manag. Sci. 2021, 77, 2971-2980. [CrossRef]

27. Chahal, P.S.; Aulakh, J.S.; Jugulam, M.; Jhala, A.J. Herbicide-Resistant Palmer amaranth (Amaranthus palmeri S. Wats) in the United States-Mechanisms of Resistance, Impact, and Management. In Herbicides, Agronomic Crops and Weed Biology; InTech: London, UK, 2015; pp. 1-30.

28. Meyers, S.L.; Jennings, K.M.; Monks, D.W. Sweetpotato tolerance and Palmer amaranth control with metribuzin and oryzalin. Weed Technol. 2017, 31, 903-907. [CrossRef]

29. Meyers, S.L.; Jennings, K.M.; Monks, D.W. Herbicide-based weed management programs for Palmer amaranth (Amaranthus palmeri) in sweetpotato. Weed Technol. 2013, 27, 331-340. [CrossRef]

30. Gonçalves Netto, A.; Nicolai, M.; Carvalho, S.J.P.; Malardo, M.R.; López-Ovejero, R.F.; Christoffoleti, P.J. Control of ALS- and EPSPS-resistant Amaranthus palmeri by alternative herbicides applied in PRE- and POST-emergence. Planta Daninha 2019, 37, 1-8. [CrossRef]

31. Iamonico, D. Taxonomic revision of the genus Amaranthus (Amaranthaceae) in Italy. Phytotaxa 2015, 199, 001-084. [CrossRef]

32. Norsworthy, J.K.; Griffith, G.; Griffin, T.; Bagavathiannan, M.; Gbur, E.E. In-field movement of glyphosate-resistant Palmer amaranth (Amaranthus palmeri) and its impact on cotton lint yield: Evidence supporting a zero-threshold strategy. Weed Sci. 2014, 62, 237-249. [CrossRef]

33. Davis, A.S.; Schutte, B.J.; Hager, A.G.; Young, B.G. Palmer Amaranth (Amaranthus palmeri) damage niche in Illinois soybean is seed limited. Weed Sci. 2015, 63, 658-668. [CrossRef]

34. Schwartz-Lazaro, L.M.; Norsworthy, J.K.; Walsh, M.J.; Bagavathiannan, M.V. Efficacy of the integrated harrington seed destructor on weeds of soybean and rice production systems in the southern United States. Crop Sci. 2017, 57, 2812-2818. [CrossRef]

35. Green, J.K.; Norsworthy, J.K.; Walsh, M.J. Distribution of common cocklebur and palmer amaranth seed exiting the combine for harvest weed seed control in soybean. Crop Forage Turfgrass Manag. 2020, 6, e20064. [CrossRef]

36. FAOSTAT Food and Agriculture Data. Available online: http://www.fao.org/faostat/en/\#home (accessed on 14 January 2021). 